\title{
The Influence of Interest, Independence and Learning Resources on Student Learning Achievement in Mathematics Lessons
}

\author{
Diana Syahfitri Nasution', Laili Habibah Pasaribu ${ }^{2}$ \\ ${ }^{1,2}$ Mathematics Education Study Program, Universitas Labuhanbatu, Indonesia \\ dianasyahfitrinst@gmail.com, laili.habibah.pasaribu@gmail.com
}

\begin{abstract}
This study aims to determine the interest, independence and learning resources of students' learning achievement in mathematics. This research uses descriptive quantitative research. The population of this study were all students of class VII MTS ArRidha Tanjung Mulia. The sample of this study uses a saturated sample, the saturated sample method is a sampling technique when all members of the population are used as the sample. Data collection techniques using a questionnaire or questionnaire with written techniques. The results of data analysis on the influence of interest in multiple regression, namely through the $t$ test, the amount of $0.014<0.05$, it is known that the $t$ count is $3.2 \mathrm{k} 10$. The result of independence thus, it is known that the value is 0067> $0.05 t$ count $1.927<t$ table 2.07387. The coefficient of determination to determine the $R$ square of independence $(X 2)$.
\end{abstract}

Keywords

interest; independence;

learning resources;

learning achievement

\section{Introduction}

According to (Sirait, 2016)Mathematics is a field of science a subject that is often encountered in schools and in everyday life. Learning mathematics does not mean that starting from elementary school to higher education, you will still learn mathematics. Therefore mathematics is called the queen of knowledge. For students, mathematics lessons are very complicated, difficult, boring, and some people find mathematics lessons challenging to test their abilities, and make curiosity bigger. Some students find it difficult with mathematics learning so that student achievement and student grades decrease, because of the lack of interest and neglect of students during learning hours, there is no curiosity about mathematics lessons, Always consider mathematics trivial. Therefore the need for guidance / education from parents outside of class hours,

Meanwhile, according to (Dewi et al., 2020) mathematics has a role in mastering science and technology. This is what makes mathematics have an important role in life and mathematics is studied at all levels of education. In studying mathematics, students have different characteristics and enthusiasm for learning. With these differences, it is necessary to have a solution to overcome the differences in the characteristics and enthusiasm of learning that students have. One solution is the use of appropriate learning approaches or methods that can be used to increase students' enthusiasm for learning. In the learning process sometimes the teacher creates a saturated learning atmosphere and makes students not contribute to the learning process, which should be that every student learning process must be able to be active. One solution to improve this is by choosing an approach or method in the teaching and learning process that can make students more independent in participating in learning activities. Therefore mathematics is a very important part for us to learn, that mathematics is important to be taught at various levels, from school to 
university, because: 1) it can be used in life, 2) can solve problems from learning mathematics, 3) it is used in every other field of science, 4) can increase thinking ability, 5) always be careful in various things. Therefore it is important to learn mathematics, both from elementary school level to college, therefore education is very important to build a child's spirit to learn and make children more active in all things,

According to (Achievement et al., 2012) can conclude, education is a conscious and planned effort to create an atmosphere of learning and the learning process so that students actively develop their potential. Education also functions to develop and shape the character and civilization of the nation. The success or failure of the teaching and learning process can be seen from the high and low level of learning achievement, children will not be smart if they do not study seriously, while the education of a student will not be successful without the achievements that they get. In education that we know students only learn at school, and are guided by the teacher, but not without us realizing that students can also be guided from home through their parents, the role of parents is very important for children, from the attention of parents it will affect learning the child,

According to (Yanti, 2019) Learning is a process of changing student behavior and curiosity which is influenced by internal and external factors. Internal factors come from within the individual, for example, physical, psychological and fatigue factors. Meanwhile, external factors come from outside the individual, for example environmental factors (family, school, and society). During the learning process there is a process of interaction between teachers and students. "Psychologically, students when participating in learning and learning activities will be influenced by factors of motivation, concentration, reaction, organization, understanding and tests. Teachers must pay attention to how to teach by knowing students, knowing their abilities, interests and independence, and the delivery of subject matter can be adjusted by these students.

To spur student interest in learning and train students to think creatively. One of the internal factors that influence the learning process is interest. According to (Yanti, 2019) Interest is a desire or a preference for something or an activity with its own will, without other people. It is known that students' interest in learning towards mathematics is still low. This is due to the lack of attention of students in receiving lessons, students are busy with their own activities, talking with their classmates, sleepy and playing alone when the teaching and learning process takes place, therefore some students just stay silent and do not want to express their opinion when asked by the teacher. By having a high interest in learning, students will be able to learn mathematics well, so that students are more easily trained to think carefully, creatively, and logically which makes students perform well in mathematics. A student who has an attitude in the discipline of learning will be diligent in doing all his duties, as a student so that it can lead to an independent attitude of students in learning. Independent learning can develop well if given the opportunity to develop through training in the form of giving assignments without assistance. Independence will have a positive impact on children's development.

(Yanti, 2019) In addition to the interest in internal factors that affect student learning achievement, independence is an attitude that occurs because self-encouragement can solve problems on their own, and does not depend on others, students can participate in learning mathematics, without experiencing difficulty learning independently, some students only depend to other friends, thus making the student's lower achievement in mathematics leads to low student learning outcomes. Some of the causes are lack of motivation to learn, boredom, and lack of student activity. According to(Dewi et al., 2020) independent is the basic word of independence which means standing alone, which is a condition where it allows someone to organize and direct themselves according to their level of development. 


\section{Research Methods}

This type of research uses quantitative descriptive research to determine the effect of interest, independence, and learning resources on student achievement in mathematics. This quantitative approach is used to determine the variable $\mathrm{X}$ and variable $\mathrm{Y}$. The variables studied are the Influence of Interest X1, Independence of X2 and Learning Resources on student achievement Y.The sample used in this study was a Saturated Sample (MTs student Ar-Ridho Tanjung Mulia)., while the population of this study were students of class VII MTS Ar-Ridha Tanjung Mulia. This research instrument is in the form of (Questionnaire) which has been tested for its validity and (test) written in the form of mathematics questions to see the results of student achievement as many as 5 questions on the material (Integer) to determine Interests.

\section{Results and Discussion}

\section{Data Analysis and Data Hypothesis Test}

Based on the results of data processing, a descriptive statistical description is obtained as in the following table:

Table 1. T test

\section{Coefficientsa}

\begin{tabular}{|c|c|c|c|c|c|c|}
\hline \multirow{2}{*}{\multicolumn{2}{|c|}{ Model }} & \multicolumn{2}{|c|}{$\begin{array}{l}\text { Unstandardized } \\
\text { Coefficients }\end{array}$} & \multirow{2}{*}{$\begin{array}{l}\text { Standardized } \\
\text { Coefficients } \\
\text { Beta }\end{array}$} & \multirow[b]{2}{*}{$\mathrm{T}$} & \multirow[b]{2}{*}{ Sig. } \\
\hline & & B & Std. Error & & & \\
\hline \multirow[t]{3}{*}{1} & (Constant) & 31,197 & 11,746 & & 2,656 &, 014 \\
\hline & Interests (X1) &, 581 &, 181 &, 533 & 3,210 &, 004 \\
\hline & $\begin{array}{l}\text { Independence } \\
\text { (X2) }\end{array}$ &, 333 &, 173 &, 320 & 1,927 &, 067 \\
\hline
\end{tabular}

a. Dependent Variable: Student Achievement (Y)

It is known that the Sig value to determine the effect of interest (X1) on student achievement $(\mathrm{Y})$ is $0.014<0.05$ and the $\mathrm{t}$ value is $3.2 \mathrm{k} 10>\mathrm{t}$ table 2.07387 , so it can be said that there is no influence of interest on student achievement.

$>$ It is known that the Sig value to determine the effect of independence on student achievement $(\mathrm{Y})$ is $0.067>0.05$ and the $t$ value is $1.927<\mathrm{t}$ table 2.07387 , so it can be concluded that there is an effect of independence on student achievement.

Table 2. Test $\mathrm{f}$

ANOVAa

\begin{tabular}{|ll|l|l|l|l|l|}
\hline \multicolumn{2}{|l|}{ Model } & Sum of Squares & Df & Mean Square & F & Sig. \\
\hline 1 & Regression & 407,493 & 2 & 203,746 & 7,125 &, $004 \mathrm{~b}$ \\
& Residual & 629,067 & 22 & 28,594 & & \\
& Total & 1036,560 & 24 & & & \\
\hline
\end{tabular}

a. Dependent Variable: Student Achievement (Y)

b. Predictors: (Constant), Independence (X2), Interests (X1) 
It is known that the Sig value to determine the effect of X1 and X2 simultaneously (simultaneously) on $\mathrm{Y}$ is $0.004<0.05$ and the $\mathrm{F}$ value of $7.125>\mathrm{F}$ table 3.42 so that it can be concluded that there is an influence of interest and independence on student achievement.

Table 3. The coefficient of determination

Model Summary
\begin{tabular}{|l|l|l|l|l|}
\hline Model & R & R Square & $\begin{array}{l}\text { Adjusted Rquare } \\
\text { Squar }\end{array}$ & $\begin{array}{l}\text { Std. Error of } \\
\text { the Estimate }\end{array}$ \\
\hline 1 &, $627 \mathrm{a}$ &, 393 &, 338 & 5,34733 \\
\hline
\end{tabular}

a. Predictors: (Constant), Independence (X2), Interests (X1)

It is known that the R square value is 0.393 , this means that the effect of interest and independence simultaneously (simultaneously) on student achievement is $39.3 \%$.

Discussion of Research Results The Effect of Student Interest, Independence and Learning Achievement on Mathematics Subjects. The results of data analysis and hypothesis testing conducted by researchers from questionnaires, and tests distributed to seventh grade students of MTs Ar-Ridho Tanjung Mulia, found that the influence of independence interest has a significant effect on student achievement.

This can be seen from the results of the influence of interest in multiple regression, namely through the $t$ test of $0.014<0.05$, it is known that $t$ count is $3.2 \mathrm{k} 10$. Meanwhile, the results obtained for t table amounted to 2.07387. The results of humanitarianism thus, it is known that the value is $0067>0.05 \mathrm{t}$ count $1.927<\mathrm{t}$ table 2.07387 so that there is an effect of interest in student achievement. The f Sig test to determine the effect of X1 and X2 simultaneously (simultaneously) on $\mathrm{Y}$ is $0.004<0.05 \mathrm{~F}$ count $7.125>\mathrm{F}$ table 3.42 , there is an effect of interest and independence on student achievement. The coefficient of determination to determine the $\mathrm{R}$ square of independence (X2), Interest (X1) of 0.393 means that the effect of interest and independence simultaneously (simultaneously) on student achievement is $39.3 \%$

This study wanted to determine the relationship between interest, independence and learning resources on student achievement in mathematics. Based on the calculation or data analysis above, it can be seen that there is a significant direct influence between interest, independence and student achievement of 0.393. This figure is relatively strong, because it can be interpreted as a significant relationship, coupled with the contribution made by the interest variable, independence towards student achievement, which is $39.3 \%$. Students' mathematics learning achievement is influenced by interest, independence.

Interest is a positive attitude that sometimes occurs in students. This condition must be suppressed as much as possible, meaning that students must strive to experience a condition that is comfortable, calm and pleasant in learning. So that students have a great interest in teaching and learning activities. Based on the description above and also the results of this study, it can be said that someone who has high interest and independence will be able to follow the learning process well so that he will be able to produce the best performance in learning, especially in mathematics. In the teaching and learning process, the most important role is a teacher who teaches or delivers lessons only to attract students' attention. 


\section{Conclusion}

Based on the results of the research and discussion, a conclusion can be drawn as follows: (1) from the results of this study, the coefficient of determination of X1 is 0.04 which states that there is a positive effect of variable X1 on Y.So it can be concluded that there is a significant influence of interest on student achievement (2) from the results of this study, the regression coefficient of X2 is 682 which states that there is a negative effect of the variable $\mathrm{X} 2$ on Y. So it can be concluded that there is a significant effect of independent learning on student achievement. (3) based on the results of the calculation of the devendent variable (X1) test for the variable (X2) obtained simultaneously (simultaneously) against $\mathrm{Y}$ is $0.004<0,05$ so it can be interpreted that the effect of interest and independence simultaneously (simultaneously) on student achievement is $39.3 \%$, it can be concluded that interest in learning has a positive effect on learning independence; (4) based on the results of the hypothesis test with the $t$ test, it can be concluded that there is a significant influence on the ability of interest, independence and learning resources on student achievement in mathematics.

\section{References}

Dewi, N., Asifa, S. N., \& Zanthy, L. S. (2020). Pengaruh Kemandirian Belajar Terhadap Hasil Belajar Matematika. PYTHAGORAS: Jurnal Program Studi Pendidikan Matematikka, 9(1), 48-54.

Laili, O. :, \& Pasaribu, H. (2020). Pengaruh Motivasi, Minat Belajar Dan Lingkungan Terhadap Prestasi Belajar Matematika Siswa. Mathematic Education Journal) MathEdu, 3(2), 106-108. http://journal.ipts.ac.id/index.php/

Laras, S. A., Rifai, A., Belajar, M., \& Belajar, H. (2019). No Title. 4(2), 121-130.

Nurmaidah, S. (2018). Upaya Meningkatkan Minat Dan Prestasi Belajar Matematika Siswa dengan Model Problem Based Learning (Pbl) Pada Siswa Kelas VII B SMP Negeri 1 Ponorogo Tahun Ajaran 2018/2019. 2012, 11-43.

Nurmalasary, N. (2018). Pengaruh Gaya Belajar dan Kemandirian Belajar terhadap Prestasi Belajar Matematika. JKPM (Jurnal Kajian Pendidikan Matematika), 3(2), 189. https://doi.org/10.30998/jkpm.v3i2.2767

Prestasi, T., Siswa, B., Mata, P., Ips, P., Vii, K., \& Negeri, S. M. P. (2012). Pengaruh Minat, Kemandirian, Dan Sumber Belajar Terhadap Prestasi Belajar Siswa Pada Mata Pelajaran Matematika. Dinamika Pendidikan, 7(1), 8-13. https://doi.org/10.15294/dp.v7i1.4913

Sirait, E. D. (2016). Pengaruh Minat Belajar Terhadap Prestasi Belajar Matematika. Formatif: Jurnal Ilmiah Pendidikan MIPA, 6(1), 35-43. https://doi.org/10.30998/formatif.v6i1.750

Suwarsito, S. (2017). Analisis Pengaruh Minat Dan Motivasi Belajar Terhadap Prestasi Belajar. Wanastra: Jurnal Bahasa Dan Sastra, 9(2), 89-98. https://doi.org/10.31294/w.v9i2.2094

Xi, K., \& Negeri, S. M. A. (2018). Kompetensi Mata Pelajaran Ekonomi Kelas Xi Sma Negeri 8 Pontianak Nim F2191141022 Program Studi S-2 Pendidikan Ekonomi Jurusan Pendidikan Ilmu Pengetahuan Sosial.

Yanti, N. R. (2019). Minat dan kemandirian belajar terhadap prestasi belajar ilmu pengetahuan sosial. Herodotus: Jurnal Pendidikan IPS, 2(1), 30-41. 